\title{
Comparison of surface properties modification by direct and active screen plasma nitriding of an ASTM M2 high-speed steel in a nitrogen rich gas mixture
}

\author{
Leonardo Fonseca Oliveira ${ }^{1 *}$ (1) \\ Alexandre da Silva Rocha ${ }^{1}$ (1) \\ Giovanni Rocha dos Santos ${ }^{1}$
}

\begin{abstract}
The active screen plasma nitriding technique has been studied in recent years as a method to optimize surface properties in steel components, avoiding the negative effects caused in the conventional Direct Current plasma treatments. In this study, ASTM M2 high-speed tool steel samples were plasma nitrided with and without the use of the active screen, in order to compare the surface properties developed by each technique. The treatments were carried out at $500{ }^{\circ} \mathrm{C}$, with the gas mixture of $76 \mathrm{vol} . \% \mathrm{~N}_{2}+24 \mathrm{vol} . \% \mathrm{H}_{2}$, for 4 and $8 \mathrm{~h}$. The active screen used was built with an expanded sheet of 304 stainless steel. The results were evaluated through optical microscopy, X-ray diffraction, and microhardness measurements. The samples were subjected to dry ball-on-flat tribological tests and the wear tracks were verified by 3D optical interferometry. The active screen use provided the formation of thinner layers, however, avoided the formation of brittle phases, resulting in the lowest wear volumes observed, up to 10 times less than the other analyzed conditions (nitrided and non-nitrided samples).
\end{abstract}

Keywords: Plasma nitriding; Active screen; ASTM M2 steel; Sliding wear.

\section{Comparação da modificação superficial por nitretação direta e por tela ativa de um aço ASTM M2 em mistura rica em nitrogênio}

\section{Resumo}

A técnica de nitretação com tela ativa vem sendo estudada nos últimos anos como uma maneira de otimizar propriedades superficiais de componentes de aço, evitando os efeitos negativos provocados nos tratamentos a plasma convencionais de corrente contínua. Neste estudo, amostras do aço rápido ASTM M2 foram submetidas a tratamentos de nitretação a plasma com e sem a utilização da tela ativa, a fim de comparar as propriedades superficiais proporcionadas por cada técnica. Os tratamentos foram executados em $500{ }^{\circ} \mathrm{C}$, com a mistura gasosa de $76 \% \mathrm{~N}_{2}+24 \% \mathrm{H}_{2}$, durante $4 \mathrm{e}$ 8 horas. A tela ativa utilizada foi construída utilizando chapa expandida de aço inoxidável AISI 304. Os resultados foram avaliados através de microscopia ótica, difração de raios-X e medidas de microdureza. As amostras foram submetidas a ensaios tribológicos do tipo esfera-sobre-plano a seco e as trilhas de desgaste foram verificadas por interferometria ótica 3D. A utilização da tela ativa proporcionou a formação de camadas menos profundas, porém, evitou a formação de fases frágeis, resultando nos menores volumes desgastados observados, até 10 vezes menor que as outras condições analisadas (amostras nitretadas e não-nitretada).

Palavras-chave: Nitretação por plasma; Tela ativa; Aço ASTM M2; Desgaste por deslizamento.

\section{Introduction}

Plasma nitriding is a thermochemical treatment applied to steel parts and tools in order to develop outstanding surface properties, the main features provided by plasma nitriding are the increase in surface hardness, wear resistance and corrosion resistance [1,2]. In the conventional Direct Current Plasma Nitriding (DCPN) method, the specimens to be treated are subjected directly to the plasma discharge that may develop a series of limitations due to specimens geometry that can

'Laboratório de Transformação Mecânica, Universidade Federal do Rio Grande do Sul-UFRGS, Porto Alegre, RS, Brasil.

*Corresponding author: leonardo.fonseca@ufrgs.br 
reduce treatment quality, or even prohibit the realization of the treatments in some parts. Some examples of these limitations are the non-uniformity of treatment temperature, overheating, surface damage due to arcing, edge effect (non-uniformity on the layers due electromagnetic fields density amplification in edges and corners) and hollow cathode effect (uncontrollable local increase in temperature due to plasma sheath overlap that takes place in holes) [3,4]. The Active Screen Plasma Nitriding (ASPN) technique was developed to bypass the restrictions of the conventional DCPN method. This technique consists of developing the glow discharge plasma in a screen structure that surrounds the nitriding parts. Such parts are electrically insulated from the equipment's main electrodes and set in a floating potential. Thus the parts can interact with the active species that are sputtered, transferred from the screen and deposited on its surface, leading to surface chemical composition changes to develop a nitrided surface while avoiding the major inconveniences that usually happen on electrically charged surfaces subjected to plasma discharges $[5,6]$.

ASTM M2 is a high-speed tool steel widely used for cutting and forming tools as for example cold work punches and dies [7]. These tools main feature is the presence of sharp and tough cutting edges, which are subjected to harsh conditions. To increase tool life, several studies developed surface engineering solutions. For nitrided M2 steel, some authors report on advantages of having a nitrided layer without the presence of the compound layer [7-15]. DCPN treatment can develop undesirable properties for M2 steel engineering applications, among them the major concern is with edge and corners embrittlement due to the non-homogeneous temperature distribution and ion bombardment in the parts. The ASPN method can develop treated surfaces without deleterious edge effects, but few studies report on comparative results for the ASPN method on the ASTM M2 steel [16-18].

In order to compare the surface properties developed by each technique (DCPN and ASPN), plasma nitriding treatments were carried out with and without the active screen in quenched and tempered ASTM M2 steel samples.

\section{Materials and methods}

Disc shaped ASTM M2 steel samples with $31.75 \mathrm{~mm}$ of diameter and $5 \mathrm{~mm}$ of height were used. Table 1 presents the chemical composition of the steel. Samples were previously quenched (from $1200^{\circ} \mathrm{C}$ ) and triple tempered (at $540{ }^{\circ} \mathrm{C}$ ). After heat treating samples were ground using 100, 240, 400, 600 and 1200 grit size silicon carbide sandpapers and polished with $3 \mu \mathrm{m}$ grain size diamond paste. Prior to each thermochemical treatment the samples were cleaned with alcohol and acetone.

The surface treatments were carried out in a cylindrical stainless-steel vacuum chamber plasma nitriding apparatus (630 $\mathrm{mm}$ in diameter and $680 \mathrm{~mm}$ in height). The nitriding parameter were as follows: 3 mbar of gas pressure; gas mixture of $\mathrm{N}_{2}: \mathrm{H}_{2}-76: 24$ vol.\%; Temperature of $500{ }^{\circ} \mathrm{C}$ (monitored by a thermocouple sensor attached to a sample); Nitriding times were 4 and 8 hours long. The nitriding apparatus is equipped with a rectified sinusoidal wave power supply, with $120 \mathrm{~Hz}$ frequency and variable voltage amplitude, the positive potential electrode (anode) is grounded and connected to the nitriding chamber outer steel wall, the negative potential electrode (cathode) is connected to the inner base plate chamber. Figure 1 shows a diagram of the specimens arrangement for both conventional and active screen nitriding setups. For the DCPN method, the samples are placed directly over the cathodic base plate electrode. In the ASPN treatments, samples were kept at a floating electric potential, being positioned in a sample holder electrically insulated from the cathodic potential by a ceramic plate. The active screen is positioned surrounding the samples, supported by the cathodic base plate. Previous experiments using a single layer active screen developed a slow heating rate. In order to accelerate the heating, a double layer screen was developed. The screen was made of two layers from expanded AISI 304 stainless steel sheet. The external screen dimensions were a diameter of $175 \mathrm{~mm}$ and a height of $190 \mathrm{~mm}$ in height. The distance from the samples' upper surface to the inner top of the screen was $60 \mathrm{~mm}$, and from sample's corner to the inner screen wall was $35 \mathrm{~mm}$.

The nitrided specimens were cross-sectioned using a low speed diamond precision blade. Sectioned samples were mounted in bakelite, ground with silicon carbide sandpapers and polished using $3 \mu \mathrm{m}$ grain size diamond paste, for the optical microscopy analysis, samples were etched using $2 \%$ Nital solution.

For each mounted samples' cross-section, Vickers microhardness profiles were determined by using a load of $0.98 \mathrm{~N}(100 \mathrm{gf})$ and a loading time of $10 \mathrm{~s}$ per indentation. $\mathrm{X}$-Ray diffraction data were acquired using a GE Seifert Charon XRD $M$ - Research Edition equipment, with BraggBrentano geometry, $\mathrm{CrK} \alpha$ radiation $(\lambda=2.2897 \AA)$ and $2 \theta$ angle ranging from $35^{\circ}$ to $166^{\circ}$.

The wear behavior was evaluated by means of non-lubricated reciprocating ball-on-flat tribological tests, having the treated samples' face as flat surface and as counter-body Zirconia balls with a diameter of $4.76 \mathrm{~mm}$. Test parameters were a normal force of $6 \mathrm{~N}$, stroke length

Table 1. Chemical composition of the ASTM M2 samples

\begin{tabular}{|c|c|c|c|c|c|c|c|c|}
\hline & $\mathrm{C}$ & Si & Mn & $\mathrm{Cr}$ & Mo & $\mathbf{V}$ & $\mathbf{W}$ & $\mathrm{Fe}$ \\
\hline Wt. $\%$ & 1.00 & 0.40 & 0.27 & 3.80 & 4.40 & 1.75 & 6.85 & Balance \\
\hline
\end{tabular}

Chemical composition verified with a Bruker Q2 Ion Optical Emission Spectrometer. 


\section{Conventional Nitriding Setup}

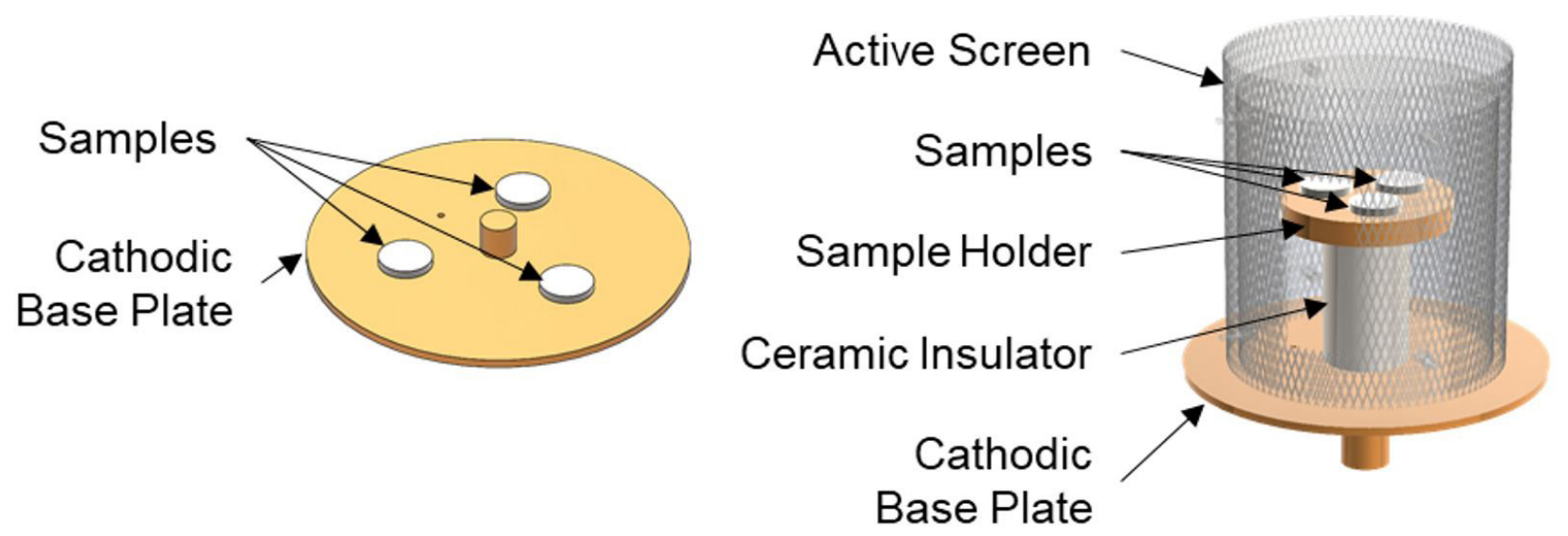

\section{Active Screen Nitriding Setup}

Figure 1. Arrangements used for the conventional and active screen nitriding experiments.

of $4 \mathrm{~mm}$, oscillating frequency of $4 \mathrm{~Hz}$ and test duration of $30 \mathrm{~min}$ (total sliding distance of $57.6 \mathrm{~m}$ ), each sample was tested four times. The wear tracks' profiles have been characterized using a Bruker Contour Elite three-dimensional interferometer. ASTM G133 standard was used to measure the mean wear volume for each sample [19].

\section{Results and discussion}

The M2 steel microstructure is composed of tempered martensite with dispersed carbides [13]. In the cross-section analysis, the typical nitrided steel promotes the formation of mainly two distinct regions: the compound layer (or white layer) in the outermost surface formed by iron nitrides and the diffusion zone underneath, were the fine precipitation of nitrides of the alloying elements are the main responsible for increasing hardness and generation of compressive residual stresses.

Cross-sectional optical microscope images of the M2 steel treated by DCPN for $4 \mathrm{~h}$ and for $8 \mathrm{~h}$ and treated by ASPN for $4 \mathrm{~h}$ and $8 \mathrm{~h}$ are shown in Figure 2a to Figure 2d, respectively. The nitrided layer etched with Nital $2 \%$ appears white for the compound layer (and primary steel carbides) and dark for the diffusion zone. The different treatment methods developed different case structures, as follow: the DCPN samples (Figure 2a and 2b) presented an evident thin (and cracking) compound layer followed by a diffusion zone underneath, whereas no compound layer was found on the ASPN treated samples (Figure $2 \mathrm{c}$ and $2 \mathrm{~d}$ ).

The different nitriding methods presented different nitrogen mass transfer mechanisms responsible for the surface modification. In the active screen method, the active species to be diffused are not generated directly on the sample surface. A portion of the generated species are lost (neutralized or deviated) in the path from the screen to the samples, so that less species end reacting and modifying the specimens surface [20]. Therefore, by using the same treatment parameters for both nitriding methods is clear that DCPN method would develop deeper layers as found in this work. In plasma nitriding, the compound layer will be formed when the nitrogen adsorption and nitride precipitation rates are higher than the dissociation and diffusion rates. For the DCPN parameters studied, the active species were in abundance and led to the saturation of nitrogen in the samples surface, promoting the precipitation of the compound layer [4]. On the other hand, for the ASPN treatment, the active species provided were not enough to saturate the sample surfaces, thus developing only the thin diffusion zones observed. It is important to point out that a DCPN treatment using a low amount of nitrogen in gas mixture also avoids compound layer formation for M2 steel [21], however the edge effect that can lead to flank embrittlement of tools could not be eliminated [10].

The hardness variation as a function of the distance from surface for the nitrided samples are shown in Figure 3.

These hardness profiles confirm the results already shown by the optical microscope images, i.e., the DCPN samples developed deeper case depths than ASPN samples. The surface hardness ranged from 1100 to $1400 \mathrm{HV}_{0.1}$. The DCPN samples developed a hardness peak in the subsurface region between 25 to $50 \mu \mathrm{m}$ deep. When Nitrogen diffuses inwards the steel it replaces Carbon in unstable carbide structures. The released Carbon then reallocates itself to stress-free regions, both to the steel surface, leading to decarburization (and lower hardness in the near-surface regions), and towards the steel core, developing a carbonenriched zone with increased hardness (as seen in the DCPN-4h profile) $[10,22]$. 


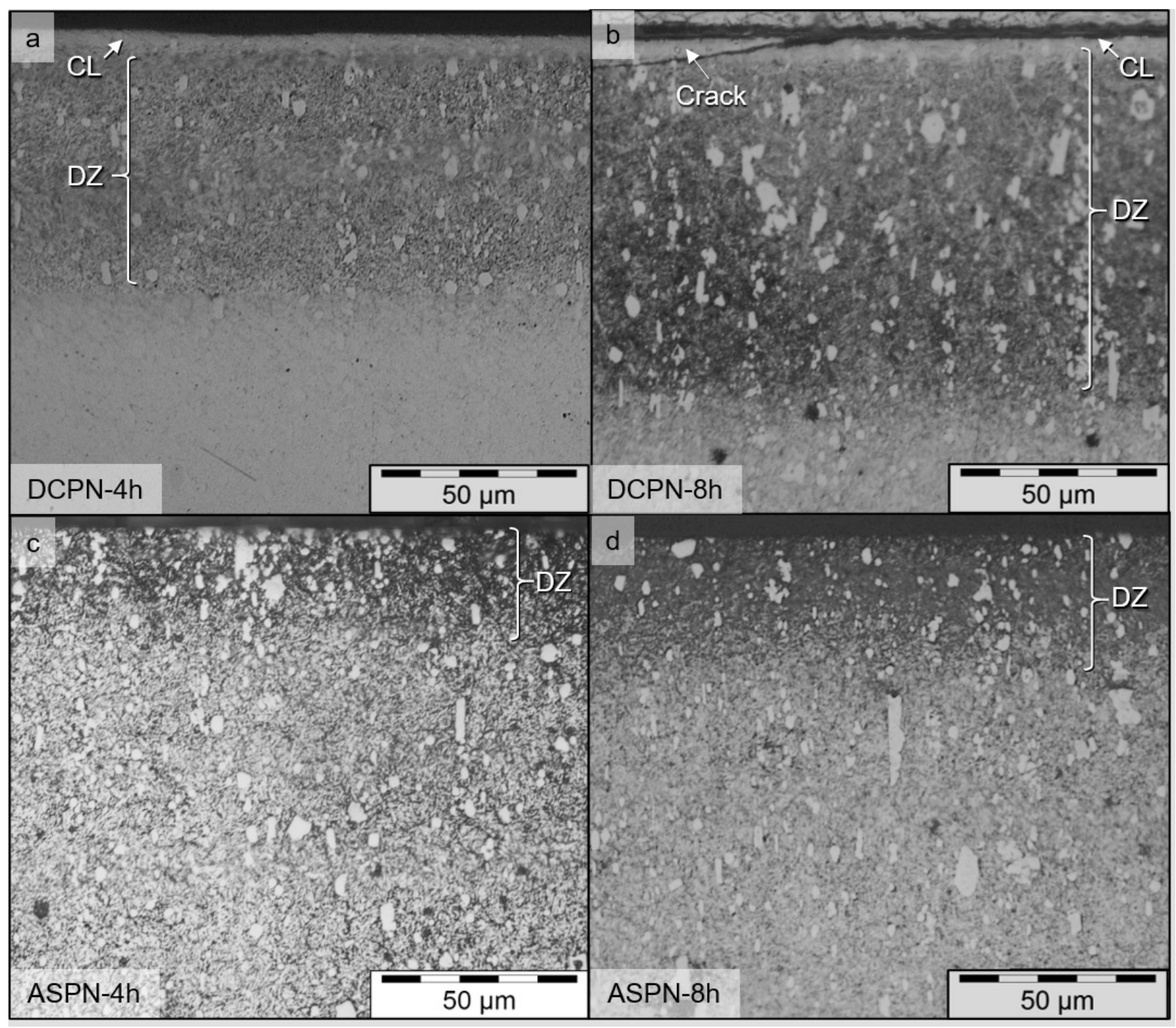

Figure 2. (a-d) Cross-section images of the nitrided samples in different conditions, etched with Nital 2\%, CL = Compound Layer, DZ = Diffusion Zone.

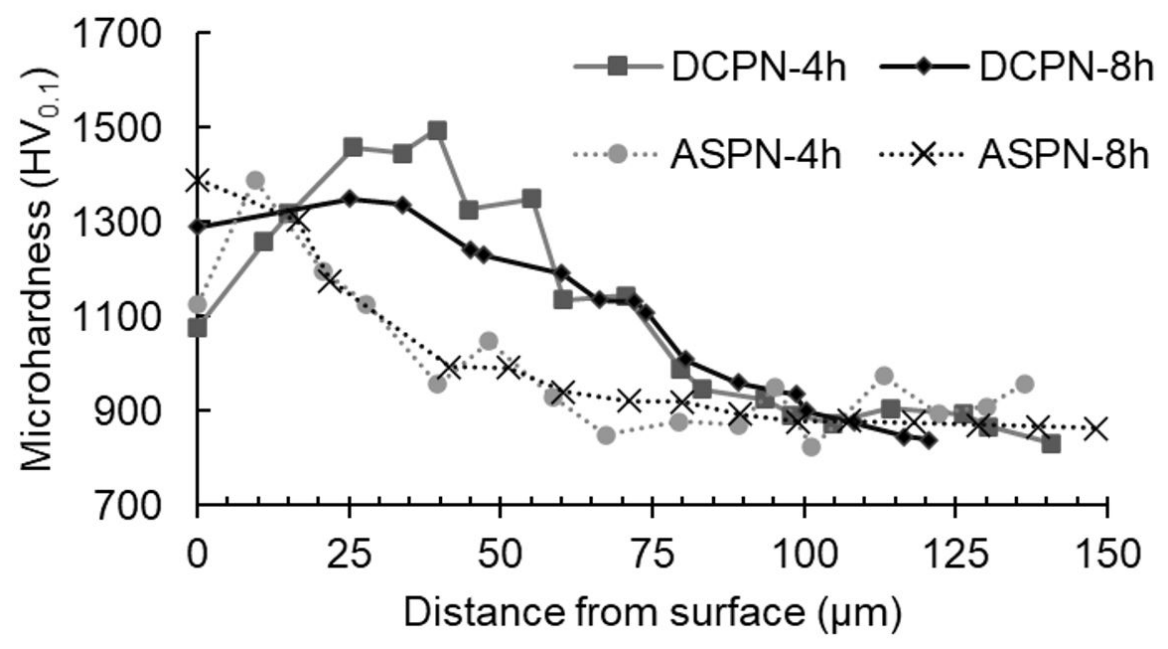

Figure 3. Microhardness profiles for the nitrided samples. The data regarding position " 0 " in the "Distance from surface" axis is from measurements taken from surface indentations, the rest are from cross-section measurements. 
Below the hardness peak both treatment methods developed a gradual hardness profile that decrease down to the hardness of the base material. The samples treated by the DCPN technique developed the overall hardness. For the DCPN treatments, the surface hardness was about $1080 \mathrm{HV}_{0.1}$ at $4 \mathrm{~h}$ treatment and $1290 \mathrm{HV}_{0.1}$ at $8 \mathrm{~h}$ treatment. The highest hardness were $1495 \mathrm{HV}_{0.1}$ and $1350 \mathrm{HV}_{0.1}$, for the 4 and 8 hour treatment respectively, both in the subsurface region between 25 and 50 micrometers, the DCPN-4h treatment developed the hardness peak due to Carbon migration, while the DCPN- $8 \mathrm{~h}$ presented a more stable hardness baseline, denoting nitrogen saturation [23]. The ASPN samples developed no compound layer and presented surface hardness values of $1127 \mathrm{HV}_{0.1}$ and $1390 \mathrm{HV}_{0.1}$, at 4 and $8 \mathrm{~h}$ of treatment, respectively.

The microhardness profiles are associated with the nitrogen diffusion [24]. The hardness increase after nitriding treatment is due to three main mechanisms: 1 . Solid solution hardening promoted by Nitrogen atoms; 2. Dispersion hardening due to nitrides formation from alloying elements.; And 3. Compressive residual stresses developed in the nitrided layer [11].

Diffusion Zone depth were measured using the hardness profiles, the end of the diffusion zone was set where the measured hardness was $50 \mathrm{HV}$ above the mean core hardness.

ImageJ software was used to measure the Compound Layer depths of the treated specimens on the micrographs (Figure 2), each specimen was measured in four different positions, the mean measured layers depths are presented in Figure 4 (error bars are set with a confidence interval of $95 \%$ ). The nitriding treatment of $8 \mathrm{~h}$ led to deeper layer for both nitriding methods, the ASPN treatment led to thinner layers than the DCPN for the same gas mixture, temperature and nitriding times.

Figure 5 presents XRD pattern of the treated samples along with the pattern for a non-nitrided sample for comparison. The base material mainly presents two sets of diffraction peaks: one from the steel matrix $(\alpha \mathrm{Fe})$ and the other from the dispersed carbide phases $\left(\mathrm{M}_{6} \mathrm{C}\right)$. Regarding phase identification of the ASPN samples, the lack of nitride phases diffraction peaks further supports the results from optical microscopic examinations where no compound layer was observed. Comparing the diffractograms from ASPN samples and base material, no new peaks were developed. The diffused nitrogen in solid solution in the diffusion zone promotes compressive residual stresses, broadening and displacing to the left the $\alpha$-iron diffracted peaks due to increase in dislocation density [25]. The XRD analysis revealed that the surface layer of DCPN samples is composed by a mixture of $\gamma^{\prime}-\mathrm{Fe}_{4} \mathrm{~N}$ and $\varepsilon-\mathrm{Fe}_{2-3} \mathrm{~N}$, but with a preponderance of $\varepsilon-\mathrm{Fe}_{2-3} \mathrm{~N}$, taking into account the higher intensity of the peaks and the information depth of the X-ray diffracting volume that for $\mathrm{Cr}$-radiation varies from 2 to $5.5 \mu \mathrm{m}$ deep for the verified $2 \theta$ range $\left(35^{\circ}\right.$ to $\left.166^{\circ}\right)$ [21].

Figure 6 summarizes the results of the ball-on-flat reciprocate tribological tests. Considering the standard deviation, the Non-nitrided specimen presented the highest wear volume. The DCPN-4h treatment increased the mean wear volume, while the DCPN-8h treatment reduced the mean wear volume. Both ASPN specimens presented the lowest wear volume compared to the non-nitrided and DCPN nitrided samples, being the ASPN-8h the best result, with volume loss nine times lower than the non-nitrided specimen and 10 times lower than the DCPN-4h treatment.

According to the literature, when ASTM M2 steel is plasma nitrided with improper treatment parameters, the Carbon present in the alloy carbides can release, migrate and reallocate themselves in the grain boundaries, promoting embrittlement of the nitrided layer $[10,12]$. Studies show that higher Nitrogen content in the gas mixture for the DCPN method can develop a brittle compound layer. Such parts, when subjected to tribological processes, develop several wear mechanisms, including spalling, adding abrasive hard

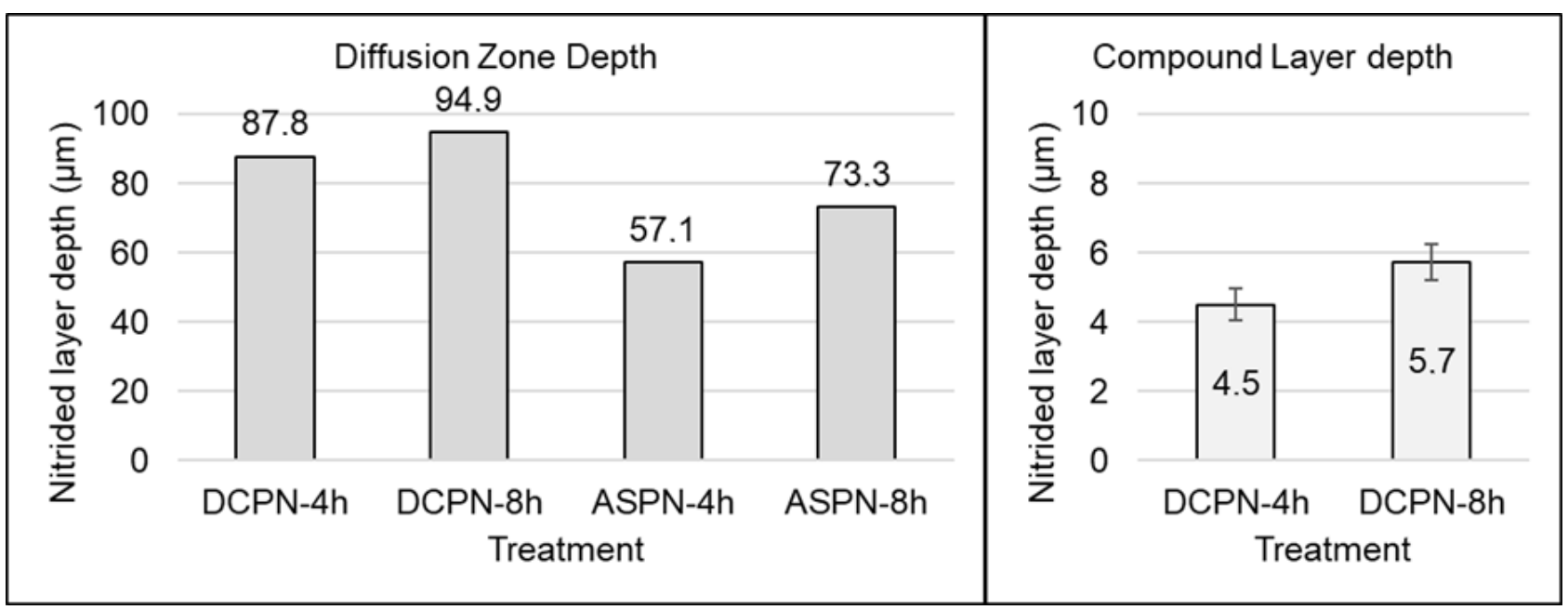

Figure 4. Nitrided layer depth measurements. Diffusion Zone depth was measured in the hardness profiles; Compound Layer depth was measured in the micrographs. 


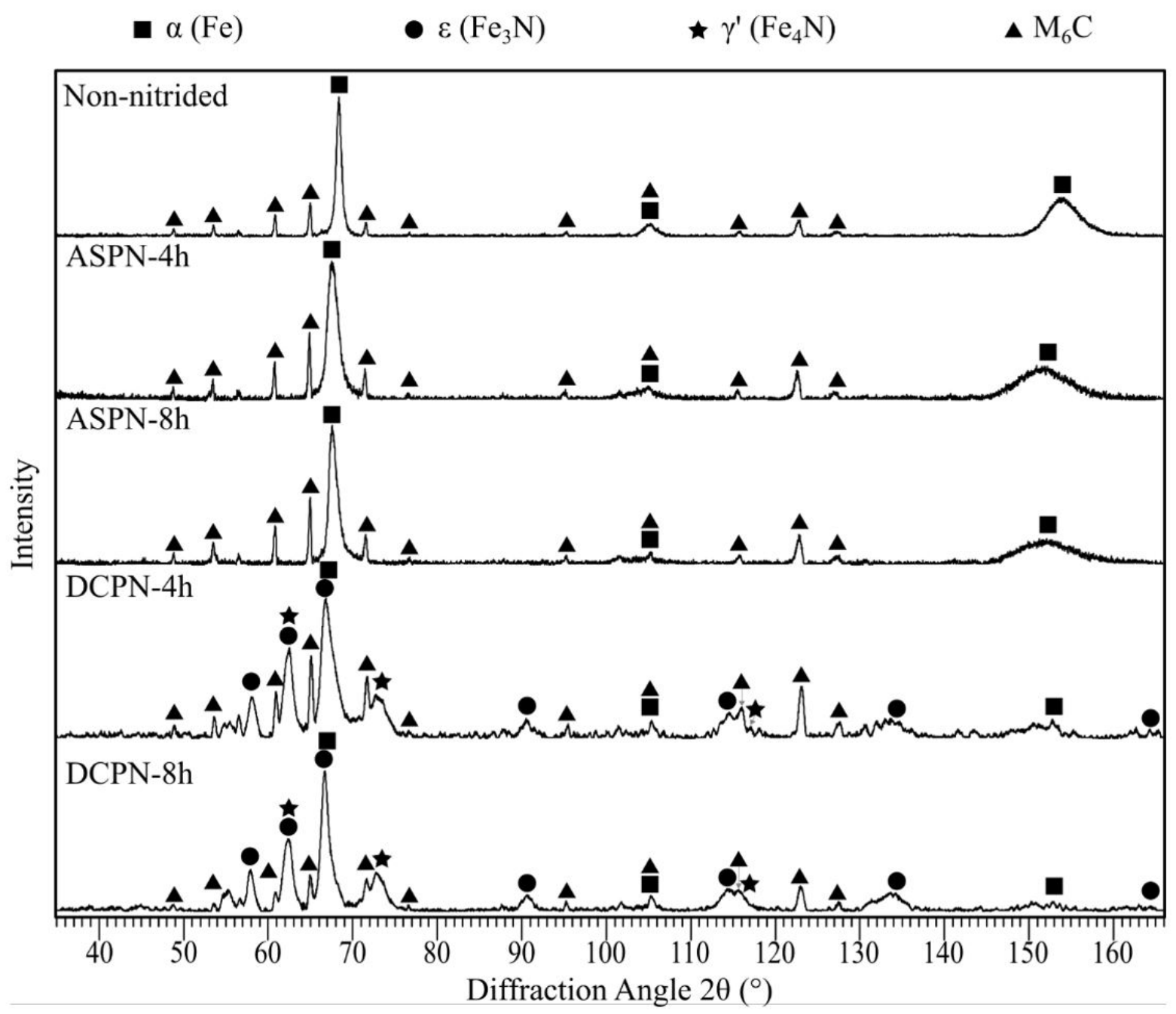

Figure 5. XRD pattern of the base material and the nitrided samples in different conditions.

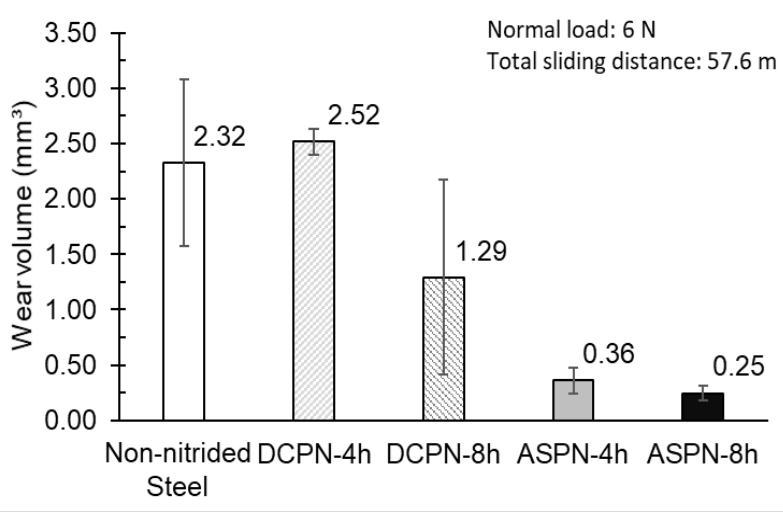

Figure 6. Wear volume for the different sample conditions tested by reciprocate ball-on-flat tribological test.

particles in the wear track that end acting as wear boosters. It is also known that in the ASPN method, there is lower interaction of the nitriding parts with the plasma active species, prolonging the nitriding time needed $[13,26,27]$. This study shows that even with a higher Nitrogen content (76\%) in the nitriding gas mixture, the expected brittle compound layer was not present in the ASPN treated specimens.

Literature suggests in cases where there is no compound layer formation, the wear rate is reduced, so the nitriding parameters must be chosen in a way to avoid formation of the compound layer for this class of steel. In DCPN treatment for M2 steel a gas mixture with low nitrogen concentration is needed, in such situation the diffused active species do not form compounds, but they allocate themselves as interstitial atoms in the specimen's lattice in solid solution, forming nitrides with alloying elements and developing compressive residual stresses $[26,28]$. The active screen modifies the kinetics of the nitrided layer formation in a way that even using a high nitrogen gas proportion no compound layer was found, evidencing that the active screen application reduces the availability of nitrogen active species needed for the nitrided layer formation. The ASPN samples surface without compound layer developed smaller wear volume, shallower wear tracks and substantial increase in the wear resistance, reaching up to 9 times lower mean wear rate than the non nitrided specimen. 
Different microstructures can be developed by applying the same nitriding parameters with different nitriding methods. For the DCPN method, despite the formation of deeper diffusion zones and higher overall hardness, a brittle compound layer took place, leading to higher wear in the tribological tests. In the ASPN method, the main difference observed was the formation of thinner layers composed only of diffusion zone, with higher wear resistance.

\section{Conclusions}

The DCPN treated samples developed the overall deeper and harder layers, with the presence of both compound layer (with a mixture of $\varepsilon$ and $\gamma^{\prime}$ nitrides) and the Diffusion zone. Although the ASPN samples developed a softer and thinner case, with the presence of only diffusion zone these samples had the best results in the tribological tests, with wear resistance up to ten times higher than the other studied cases, this result is attributed to the non-formation of a brittle compound layer. It was observed that increasing the treatment time can lead to poorer results or no substantial increments for the studied properties.

This study shows that the nitriding parameters must be chosen carefully in order to achieve optimized surface properties for different applications and the differences in treatment methodologies must not be ignored because the results can vary drastically from the DCPN and ASPN treated samples.

\section{Acknowledgements}

This study was supported by the Coordenação de Aperfeiçoamento de Pessoal de Nível Superior (CAPES, Brasil), Conselho Nacional de Desenvolvimento Científico e Tecnológico (CNPq, Brasil, Universal, process number 435795/2018-0) and Fundação de Amparo à Pesquisa do Estado do Rio Grande do Sul (FAPERGS, Brasil, process 17/2551-0001023-0)

\section{References}

1 Czerwinski F. Thermochemical treatment of metals. In: Czerwinski F, editor. Heat treatment - conventional and novel applications. London: InTech; 2012. http://dx.doi.org/10.5772/51566.

2 Yetim AF, Yildiz F, Vangolu Y, Alsaran A, Celik A. Several plasma diffusion processes for improving wear properties of Ti6Al4V alloy. Wear. 2009;267(12):2179-2185. http://dx.doi.org/10.1016/j.wear.2009.04.005.

3 Kovács D, Kemény A, Dobránszky J, Quintana I. Effects of plasma nitriding on tempered steel. IOP Conference Series: Materials Science and Engineering; 2018;426:012027. http://dx.doi.org/10.1088/1757-899X/426/1/012027.

4 Mittemeijer EJ, Somers MAJ. Thermochemical surface engineering of steels. Sawston, Cambridge: Woodhead Publishing; 2015.

5 Li CX. Active screen plasma nitriding - an overview. Surface Engineering. 2010;26(1-2):135-141. http://dx.doi. org/10.1179/174329409X439032.

6 Gallo SC. Active screen plasma surface engineering of austenitic stainless steel for enchanced tribological and corrosion properties. Birmingham: University of Birmingham; 2009.

7 Rousseau AF. Metallurgical characterization and performance of high speed steel tool materials used in metal cutting applications. Melbourne: Swinburne University of Technology; 2016.

8 Ozbaysal K, Inal OT, Romig AD Jr. Ion-nitriding behavior of several tool steels. Materials Science and Engineering. 1986;78(2):179-191. http://dx.doi.org/10.1016/0025-5416(86)90322-8.

9 Rocha A S. Influência do estado superficial prévio na nitretação a plasma do aço AISI M2 [tese]. Porto Alegre: Universidade Federal do Rio Grande do Sul; 2000.

10 Kwietniewski C, Fontana W, Moraes C, Rocha AS, Hirsch T, Reguly A. Nitrided layer embrittlement due to edge effect on duplex treated AISI M2 high-speed steel. Surface and Coatings Technology. 2004;179(1):27-32. http:// dx.doi.org/10.1016/S0257-8972(03)00795-3.

11 Akbari A, Mohammadzadeh R, Templier C, Riviere JP. Effect of the initial microstructure on the plasma nitriding behavior of AISI M2 high speed steel. Surface and Coatings Technology. 2010;204(24):4114-4120. http://dx.doi. org/10.1016/j.surfcoat.2010.05.042.

12 Tier M, Bloyce A, Bell T, Strohaecker T. Wear of plasma nitrided high speed steel. Surface Engineering. 1998;14(3):223-227. http://dx.doi.org/10.1179/sur.1998.14.3.223.

13 Mohammadzadeh R, Akbari A, Drouet M. Microstructure and wear properties of AISI M2 tool steel on RF plasma nitriding at different N2-H2 gas compositions. Surface and Coatings Technology. 2014;258:566-573. http://dx.doi. org/10.1016/j.surfcoat.2014.08.036. 
14 Pessin MA, Tier MD, Strohaecker TR, Bloyce A, Sun Y, Bell T. The effects of plasma nitriding process parameters on the wear characteristics of AISI M2 tool steel. Tribology Letters. 2000;8(4):223-228. http://dx.doi. org/10.1023/A:1019199604963.

15 Hacisalihoglu I, Yildiz F, Alsaran A. Wear performance of different nitride-based coatings on plasma nitrided AISI M2 tool steel in dry and lubricated conditions. Wear. 2017;384-385:159-168. http://dx.doi.org/10.1016/j. wear.2017.01.117.

16 Naz MY, Shukrullah S, Javaid MA, Ghaffar A, Rehman NU. Surface hardening of M2 high speed steel using $50 \mathrm{~Hz}$ pulsed DC source with nitrogen as a base gas. Synthesis and Reactivity in Inorganic Metal-Organic and Nano-Metal Chemistry. 2015;45(7):1057-1062.

17 Doyle ED, Pagon AM, Hubbard P, Dowey SJ, Pilkington A, McCulloch DG, et al. Nitriding of high speed steel. Int Heat Treat Surf Eng. 2011;5(2):69-72. http://dx.doi.org/10.1179/174951411X12956208225348.

18 Abreu LHP, Pimentel MCL, Borges WFA, Costa THC, Naeem M, Iqbal J, et al. Plasma nitriding of AISI M2 steel: performance evaluation in forming tools. Surface Engineering. 2020;36(5):1-8. http://dx.doi.org/10.1080/02670844. 2020.1727685 .

19 ASTM International. ASTM G133-05 (2016) - Standard Test Method for Linearly Reciprocating Ball-on-Flat Sliding Wear. West Conshohocken, PA: ASTM International; 2016.

20 Zhao C, Li CX, Dong H, Bell T. Study on the active screen plasma nitriding and its nitriding mechanism. Surface and Coatings Technology. 2006;201(6):2320-2325. http://dx.doi.org/10.1016/j.surfcoat.2006.03.045.

21 da Silva Rocha A, Strohaecker T, Tomala V, Hirsch T. Microstructure and residual stresses of a plasma-nitrided M2 tool steel. Surface and Coatings Technology. 1999;115(1):24-31. http://dx.doi.org/10.1016/S0257-8972(99)00063-8.

22 Tier MA, Kieckow F, Strohaecker TR, Rocha AS. A study of carbon redistribution during plasma nitriding of steel. In: Proceedings of the 15th IFHTSE - International Federation for Heat Treatment and Surface Engineering; 2006; Vienna. Leoben: ASMET - The Austrian Society for Metallurgy and Materials; 2006. p. 193-199.

23 Berg M, Budtz-Jørgensen CV, Reitz H, Schweitz KO, Chevallier J, Kringhøj P, et al. On plasma nitriding of steels. Surface and Coatings Technology. 2000;124(1):25-31. http://dx.doi.org/10.1016/S0257-8972(99)00472-7.

24 Hill MP, Pankhurst KS. Microhardness and nitrogen concentration profiles for nitrided 316 steel. Surface Technology. 1979;8(3):253-262. http://dx.doi.org/10.1016/0376-4583(79)90018-9.

25 Sun Y, Li XY, Bell T. X-ray diffraction characterisation of low temperature plasma nitrided austenitic stainless steels. Journal of Materials Science. 1999;34(19):4793-4802. http://dx.doi.org/10.1023/A:1004647423860.

26 Alsaran A. Determination of tribological properties of ion-nitrided AISI 5140 steel. Materials Characterization. 2002;49(2):171-176. http://dx.doi.org/10.1016/S1044-5803(03)00008-1.

27 Rocha AS, Strohaecker T, Tomala V, Hirsch T. Microstructure and residual stresses of a plasma-nitrided M2 tool steel. Surface and Coatings Technology. 1999;115(1):24-31. http://dx.doi.org/10.1016/S0257-8972(99)00063-8.

28 Hirsch T, Rocha A, Ramos F, Strohaecker TR. Residual stress-affected diffusion during plasma nitriding of tool steels. Metallurgical and Materials Transactions. A, Physical Metallurgy and Materials Science. 2004;35(11):35233530. http://dx.doi.org/10.1007/s11661-004-0189-2.

Received: 14 Aug. 2020

Accepted: 10 Feb. 2021 